\title{
Saying Credibly What the Law Is: On Marks of Authority in International Law
}

\author{
FUAD ZARBIYEV*
}

\begin{abstract}
It is no longer contested that statements of international law issued by various international actors play an important part in shaping the content of international law in a way that cannot be explained by reference to formal legal entitlements. This article argues that the concept of authority is particularly well-suited to account for the normative effects of such statements. Building on rhetoric, sociology and political philosophy, it conceptualizes authority as deference entitlement and identifies four marks of authority to say what the international law is that are not coextensive with the formal power to compel through binding decisions. It then turns to broader implications of this concept of authority for international law and concludes with suggestions for possible further research.
\end{abstract}

During the US Senate hearing on ratification of the United Nations Convention on the Rights of Persons with Disabilities, several members of the Foreign Relations Committee pressed the then Secretary of State John F. Kerry to reassure them that joining the Disabilities Convention would have no impact on the United States. Applying himself to this task with characteristic vigour, Secretary Kerry set out to convince the Committee members that the Committee on the Rights of Persons with Disabilities - a body of independent experts under the Convention with the mandate to monitor the implementation of the latter-was an institution with 'zero power'. After pointing out that the Convention had 'no impact whatsoever on the sovereignty of the United States', Secretary Kerry went on to describe the Disabilities Committee as follows:

[J]oining this treaty does not require a change to U.S. law, and there is no reach whatsoever by any committee or any entity outside. The one committee

* Assistant Professor of International Law (The Graduate Institute of International and Development Studies, Geneva). Email: fuad.zarbiyev@graduateinstitute.ch. Prior versions of this article were presented at the 25th Annual SLS-BIICL Conference on Theory and International Law, and at the Faculty Workshop of the Department of International Law of the Graduate Institute of Geneva to the participants of which I owe thanks for their constructive engagement with my argument. I am also grateful to Andrea Bianchi, Nico Krisch, Linus Muehrel, Lisandra Novo, Joost Pauwelyn, Thomas Schultz, Aliki Semertzi and Sandesh Sivakumaran, as well as two anonymous reviewers for their insightful comments on earlier drafts of this article.

(C) The Author(s) 2018. Published by Oxford University Press. All rights reserved.

For permissions, please e-mail: journals.permissions@oup.com 
that exists within the framework of this treaty is allowed to suggest things, but they have no power to enforce, no power to compel, no power to do anything except put an idea on the table. Nothing can change unless the U.S. Senate were to reratify whatever suggestion the U.S. Senate might engage in subsequently... . There is no oversight. There is a committee that works on issues, but the most that they can do is make a suggestion... . [T]he Disabilities Committee has absolutely zero power to change a law, to order a change of law, to compel a change of law. They cannot have any impact. There is no power in this treaty, also in the committee. . . No decision, memo, anything that they utter can have an impact on the United States. ${ }^{1}$

Echoing Secretary Kerry's comments, the Report of the Foreign Relations Committee specified that ' $[\mathrm{s}]$ tates parties to the Convention are not required to give greater weight to the interpretation of the Convention by the Disabilities Committee than they do their own interpretation, and are not required to conform their interpretations to or make them consistent with those of the Disabilities Committee."2

The purpose of this article is not to evaluate the substantive merits of the position defended by Secretary Kerry or that set forth in the Report of the Foreign Relations Committee, but to engage with the broader unarticulated assumption that underpins those positions, which is that the authority of an international institution hinges upon its power to issue formally binding decisions. To appreciate how pervasive that assumption is, it may be illuminating to compare the positions of Secretary Kerry and the Senate Foreign Relations Committee with the view of the UN Office of the High Commissioner on Human Rights on the legal effects of the Opinion issued by the Working Group on Arbitrary Detention regarding the WikiLeaks founder Julian Assange. ${ }^{3}$ As has been widely reported, the Working Group held in that Opinion that Julian Assange's initial detention, house arrest and confinement in the Embassy of Ecuador in London constituted an arbitrary detention. ${ }^{4}$ In its press release reporting on the Opinion, the Office of the High Commissioner stated that ' $[t]$ he Opinions of the Working Group on Arbitrary Detention are legally-binding to the extent that they are based on binding international human rights law, such as the International Covenant on Civil and Political Rights.'

Even though their immediate subject-matters and concerns obviously differ, the discussion of the powers of the UN Disabilities Committee in the US Senate and the press release of the Office of the High Commissioner involve the same question on substance, namely what are the effects of decisions of international institutions that

1 Convention on the Rights of Persons with Disabilities (Treaty Doc 112-7), 113th Congress, 2nd Session, 158, 166. Secretary Kerry may have performed too well, since his comments prompted a member of the Committee to ask: 'if ... the treaty does not compel us to do anything except to continue to follow our own law in our own way, why then ratify it?' ibid 166.

2 ibid 10.

3 Opinion No 54/2015 concerning Julian Assange (Sweden and the United Kingdom of Great Britain and Northern Ireland), A/HRC/WGAD/2015, 22 January 2016.

4 ibid paras 86-90.

5 'Julian Assange arbitrarily detained by Sweden and the UK, UN expert panel finds', 5 February 2016 $<$ http://ohchr.org/EN/NewsEvents/Pages/DisplayNews.aspx?NewsID =17013\&LangID =E $>$ accessed 15 January 2018. 
have not been formally empowered to issue binding decisions? The response that emerged in the US Senate Foreign Relations Committee and the position of the UN Office of the High Commissioner may seem diametrically opposed, but they share a common operating assumption. The conclusion reached by the US Senate Foreign Relations Committee was on substance based on the absence of a power granted to the UN Disabilities Committee to issue binding decisions, whereas the UN Office of the High Commissioner tried to make up for that lack by tying the authority of the Working Group on Arbitrary Detention to formally binding legal instruments. ${ }^{6}$

The primary objective of the present article is to problematize this common assumption by showing that authority experiences in international law are a much more complex phenomenon that cannot be reduced to the power to compel through binding decisions. This argument will be developed with respect to a specific kind of authority, namely the authority to determine the content of international law on a particular point and state where international law stands on that point. The definition of international law that will be followed in this article is the conventional one, which means that the focus of this article is the authority to say what the international law is, but not the threshold question of what is international law. ${ }^{7}$ Consider questions such as: How can formally non-binding decisions play a role in shaping the content of international law? On which grounds can a binding decision have normative significance beyond the specific context to which its effects are formally confined? How do legal operators discriminate among conflicting decisions in a system that knows no formal hierarchy? I contend that the concept of authority is particularly well-suited to respond to such questions.

This article will proceed in three parts. Section 1 attempts to develop a conceptual framework within which the phenomenon of authority can be fruitfully approached in international law. Section 2 will be devoted to various 'marks' of authority that can be observed in international legal discourse. The final part will focus on some broader conceptual implications of the approach developed in this article.

\section{AUTHORITY AS DEFERENCE ENTITLEMENT}

The concept of authority is an excellent candidate to illustrate Nietzsche's famous observation that 'only that which has no history is definable'. '[A] concept with a rich and complicated history', 9 authority has been used, interpreted and reinterpreted in so many disciplinary and practical contexts in the service of such a variety of purposes that any attempt at capturing it by a single definition would be liable of charges

6 For a similar attempt to explain the authority of the decisions of the Human Rights Committee, see Sarah Joseph and Melissa Castan, The International Covenant on Civil and Political Rights: Cases, Materials and Commentary (3rd edn, OUP 2013), 22 ('The HRC is the pre-eminent interpreter of the ICCPR which is itself legally binding. The HRC's decisions are therefore strong indicators of legal obligations, so rejection of those decisions is good evidence of a State's bad faith attitude towards its ICCPR obligations.').

7 On this distinction, see Special Report by Sir Gerald Fitzmaurice, The Future of Public International Law and of the International Legal System in the Circumstances of Today, in Institut De Droit International. Livre Du Centenaire 1873-1973 (1973) 251.

8 Friedrich Nietzsche, Beyond Good and Evil/On The Genealogy of Morality (Stanford University Press 2014) 268.

9 Roger Cotterrell and Maksymilian Del Mar, 'Introduction', in Roger Cotterrell and Maksymilian Del Mar (eds), Authority in Transnational Legal Theory (Edward Elgar 2016) 1. 
of misrepresentation from some perspective. ${ }^{10}$ Strangely enough, legal scholars who have written on the concept of authority have rarely been sensitive to the rich history of this concept and have often limited themselves to uncritically reproducing the theoretical framework offered by analytical jurisprudence. Joseph Raz's theory of authority has proved particularly influential in this regard. ${ }^{11}$ According to Raz, a directive is authoritatively binding if it operates as content-independent and pre-emptive reasons for action. The content-independence means that an authoritative directive is complied with not because its content is found sound or agreeable, but because it is issued by a particular person. ${ }^{12}$ The pre-emptive nature of authoritative directives as reasons for action refers to the fact that they are not balanced against other relevant considerations, and that they exclude possible countervailing reasons for action. ${ }^{13}$ An important part of Raz's theory of authority is his discussion of the conditions under which authority is justified. ${ }^{14}$

Interestingly, Raz is the first to admit that his theory 'depart[s] too far from many of the ideas that have gained currency in the history of reflection on authority'. ${ }^{15}$ What follows is an attempt to rehabilitate some of those ideas that have not had the fair opportunity to be heard in the discipline of international law for the simple reason that they have rarely been introduced to the audience of international lawyers. The purpose in attempting such a thing is not simply to show that alternative theories exist, but also explain how they help understand some of the real-life authority experiences in international law. Inspired by long-standing discussions of authority in rhetorical studies, political philosophy and sociology, the concept of authority offered in this article has little in common in spirit with the often sterile scholasticism of analytical jurisprudence. It is not based on, or influenced by, any normative consideration on what authority should be or under what circumstances it is justified; the sole concern behind the concept of authority presented herein is to account for a social phenomenon in terms informed by experience. ${ }^{16}$

At a high level of generality, authority can be described as a mode of regulating behaviour. What differentiates authority in the sense developed in this article from other modes of regulation is the reason why it determines behaviour. An authoritative utterance determines behaviour not because of a threat of sanction (or a promise of a reward), or through persuasion, but because it emanates from a particular

10 RB Friedman, 'On the Concept of Authority in Political Philosophy', in Joseph Raz (ed), Authority (NYU Press 1990) 57, 56-91 (observing that 'there is no single view of authority that can serve as the model for understanding all the different uses to which it is put.').

11 For a helpful summary of Raz's theory of authority, see Samantha Besson, 'The Authority of International Law - Lifting the State Veil' (2009) 31 Sydney Law Review 351.

12 Joseph Raz, The Morality of Freedom (Clarendon Press 1986) 35-37.

13 ibid 57-62.

14 ibid 42-57.

15 Joseph Raz, 'The Problem of Authority: Revisiting the Service Conception' (2006) 90 Minnesota Law Review 1003.

16 This approach was recently described as 'a social-legal view - one that sees the practices and experiences of authority as empirical social phenomena and considers how they can be observed and interpreted.' Cotterrell, 'Transnational Legal Authority: A Socio-Legal Perspective', in Cotterrell and Del Mar (n 9) 262. 
person. ${ }^{17}$ Exclusion of both coercion and rational persuasion is thus inherent in the very definition of authority as discussed in this article. ${ }^{18}$

Authority is often linked to the right to command and the corresponding obligation to obey. Unless further specified, this approach adds to the difficulty of untangling the concept of authority rather than clarifying it. To start with, it assumes a hierarchical relation between an authority-holder and a set of identifiable subjects, whereas authority of a person or an institution as outlined above can manifest itself outside any hierarchical relationship and without any intention to bind any particular person. Thus, the 'command and obligation' model elevates a particular manifestation of authority to the very definition of the general phenomenon of authority, and as such, may be missing the tree for the forest. ${ }^{19}$ It is also unclear what the right to command' and 'the obligation to obey' mean in this model; they may be officially formalized as in the case of legal rights and obligations, only socially sanctioned, or both at the same time.

The reflections on authority in rhetoric, political philosophy and sociology offer an alternative and arguably more fruitful way of theorizing authority. One common thread that runs through many of these reflections is that authority is 'deference entitlement'. ${ }^{20}$ As such, it does not imply an obligation in the traditional sense of this term, but a voluntary submission. ${ }^{21}$ But how can submission to authority be voluntary, if voluntariness implies the existence of a choice? This 'paradox between

17 Friedman (n 10) 69 (stating that in an authority relationship a command is obeyed, a pronouncement accepted, etc, on account of who it comes from, rather than as a result of an evaluation of its merits.').

18 In the famous words of Hannah Arendt, '[a] father can lose his authority by beating his child or by starting to argue with him.' Hannah Arendt, On Violence (Harcourt, Brace \& World 1970) 45. The point was already made by Kierkegaard. Soren Kierkegaard, Without Authority (Princeton University Press 2009) 101, 104. See also, RF Khan, 'A Note on the Concept of Authority', in Gehan Wijeye-wardene (ed), Leadership and Authority. A Symposium (University of Malaya Press for Southeast 1968) 12, 14; RS Peters, 'Symposium on Authority' (1958) 32 Proceedings of the Aristotelian Society 218; Frank Furedi, Authority. A Sociological History (CUP 2013) 8; Bruce Lincoln, Authority. Construction and Corrosion (University of Chicago Press 1994) 5; Alexandre Kojève, The Notion of Authority (A Brief Presentation) (Verso 2014) 10.

19 Michel Foucault famously observed that political philosophy still needs 'to cut off the king's head' in its analysis of power relationships. Foucault was alluding to the fact that political theory was dominated by the juridical conception of power, the one analysing power in terms of legal prescriptions and prohibitions and attempting to trace it to an ultimate source, whether in the form of the person of the king or some analogous alternatives. Michel Foucault, Power: Essential Works of Foucault 1954-1984 (James D Faubion ed, The New Press 2001) 122.

20 The phrase 'deference entitlement' is borrowed from Edward Shils, Center and Periphery: Essays in Macrosociology (University of Chicago Press 1975) vol 2, 283. On the deference-based understanding of authority, see Michael Barnett and Martha Finnemore, Rules For The World: International Organizations in Global Politics (Cornell University Press 2004) 5; Ingo Venzke, 'Between Power and Persuasion: On International Institutions' Authority in Making Law' (2013) 4 Transnational Legal Theory 354; Ole Jacob Sending, The Politics of Expertise: Competing for Authority in Global Governance (The University of Michigan Press 2015) 19; Nico Krisch, 'Authority, Solid and Liquid, in Postnational Governance', in Cotterrell and Del Mar (n 9), 25-48.

21 This feature of authority was emphasized by Max Weber for whom 'a certain minimum of voluntary submission' was inherent in every authority relation. See Max Weber, The Theory of Social and Economic Organization (Free Press 1964) 324. See also, Kojève (n 18) 8; Peter M Blau, 'Critical Remarks on Weber's Theory of Authority' (1963) 57 The American Political Science Review 306; Herbert Marcuse, Studies in Critical Philosophy (Beacon Press 1972) 51; Barnett and Finnemore (n 20) 20. 
voluntarism and authoritarian control ${ }^{22}$ cannot be resolved if one loses sight of the social basis of authority. Authority does not rest on individual choices, but on 'a belief system' that socially sanctions it. ${ }^{23}$ The community in which this belief system emerges and its individual members are not subject to authority in the same manner. If the collective belief system supporting authority within a community disappears, authority itself will disappear; but so long as that belief system effectively exists in the community, authority is obeyed by its individual members as a result of 'compelling social pressures. ${ }^{24}$

The well-known argument from authority in rhetoric sheds a great deal of light on the concept of authority offered in this article. As pointed out in a treatise on argumentation, an argument from authority 'uses the acts or opinions of a person or group of persons as a means of proof in support of a thesis. ${ }^{25}$ The audience to which such an argument is addressed is invited to accept a thesis not because of its intrinsic merits, but because it is supported by a person or an institution treated as authority.

There is no meaningful sense in which those who are treated as authorities in matters of knowledge can be said to issue commands to a set of identifiable subjects. Likewise, a person or an institution using the argument from authority does not necessarily act out of a sense of formal obligation towards the person or institution treated as authority. But the fact that a person or an institution is treated as authority often generates a sense of deference entitlement. In a similar vein, those who use the argument from authority may not feel that they have a choice in any meaningful sense. It should be recalled that in its original formulation by John Locke, the argument from authority was the "argument on shame" because one should not dare to question the authority mentioned in the argument." 26

It is not difficult to appreciate why this particular understanding of authority has somewhat fallen into disrepute. ${ }^{27}$ As nicely put by Corbett and Connors, ' $[\mathrm{i}] \mathrm{n}$ an age characterized by a scientific attitude and a democratic spirit, people are temperamentally not as disposed as they once were to be impressed and swayed by the voice of

Blau (n 21) 307; Marcuse (n 21) 51 (stating that in the authority relationship freedom and unfreedom, autonomy and heteronomy, are yoked in the same concept and united in the single person of he who is subject.')

Blau (n 21) 307.

24 ibid 312.

25 Chaïm Perelman and Lucie Olbrechts-Tyteca, The New Rhetoric. A Treatise on Argumentation (The University of Notre Dame Press 1971) 305.

26 Frans H Van Eemeren, 'Fallacies', in Thomas O Sloane (ed), Encyclopedia of Rhetoric (OUP 2001) 296. See John Locke, An Essay Concerning Human Understanding (T Tegg and Son 1836) 524, ('When men are established in any kind of dignity, it is thought a breach of modesty for others to derogate any way from it, and question the authority of men, who are in possession of it. This is apt to be censured, as carrying with it too much of pride, when a man does not readily yield to the determination of approved authors, which is wont to be received with respect and submission by others; and it is looked upon as insolence for a man to set up, and adhere to, his own opinion against the current stream of antiquity; or to put it in the balance against that of some learned doctor or otherwise approved writer. Whoever backs his tenets with such authorities, thinks he ought thereby to carry the cause, and is ready to style it impudence in any one who shall stand out against them. This, I think, may be called argumentum ad verecundiam.').

27 Hannah Arendt famously observed that 'authority has vanished from the modern world'. Hannah Arendt, Between Past and Future (Penguin 2006) 91. 
authority and the pronouncement of people "in the know." 28 The notion that an opinion or a view should be believed solely because it was put forward by someone is anathema to the Enlightenment, which continues to govern our cognitive dispositions. ${ }^{29}$ Kant famously defined the Enlightenment as 'mankind's exit from its selfincurred immaturity', describing immaturity as 'the inability to make use of one's own understanding without the guidance of another'. ${ }^{30}$ A cultural environment hostile to subordinating one's views to 'the guidance of another' cannot be hospitable to authority, since the latter assumes 'unquestioning' submission. ${ }^{31}$ It is thus not surprising that the argument from authority has long been treated as a fallacy and 'an evasion from the law of rationality. 32

But the role of 'the guidance of another' in matters of knowledge has little been affected by the Enlightenment for obvious pragmatic reasons. After all, we are not expected to engage in a scientific investigation about a medical diagnosis offered by our doctor before placing our trust in it or test water in a laboratory to be certain that its chemical composition is in effect $\mathrm{H} 2 \mathrm{O}$. This shows that the issue is not whether one should trust 'the guidance of another', but when the trust in such guidance is justified. ${ }^{33}$ As noted by Stitch and Nisbett, we learn how to appropriately place our cognitive trust in others as a result of our socialization as competent members of the society. ${ }^{34}$

This latter point captures what is central to every authority relationship, namely 'a certain kind of "recognition" that the person to whom one defers is entitled to this short of submission. ${ }^{35}$ If authority is 'the right to speak credibly' ${ }^{36}$, who has such a right is a matter of social recognition.

28 Edward PJ Corbett and Robert J Connors, Classical Rhetoric for the Modern Student (4th edn, OUP 1999) 113. See also, Patrick Wilson, Second-Hand Knowledge. An Inquiry into Cognitive Authority (Praeger 1983) 13 (stating that ' $[\mathrm{t}]$ he very mention of authority is likely to produce strong emotions, usually hostile.').

29 See Michel Foucault, 'What is Enlightenment?' in Michel Foucault, Ethics. Subjectivity and Truth: The Essential Works of Michel Foucault 1954-1984 (James D. Faubion ed, The New Press 1997) 303 (observing that the Enlightenment 'has determined, at least in part, what we are, what we think, and what we do today'.)

30 Immanuel Kant, 'An Answer to the Question: What is Enlightenment?' in James Schmidt (ed), What Is Enlightenment? Eighteenth-Century Answers and Twentieth-Century Questions (The University of California Press 1996) 58.

31 Arendt (n 18) 45. On the effect of the Enlightenment on authority, see Furedi (n 18) 207.

32 Lionel Ruby, Logic: An Introduction (Lippincott 1950) 128.

33 Christopher W Tindale, Fallacies and Argument Appraisal (CUP 2007) 127. This is why the argument from authority is sometimes called 'a part-time fallacy', which means that, while there is nothing wrong with the argument as such, it may be employed in a fallacious manner. See Edwin Coleman, 'There is no Fallacy of Arguing from Authority' (1995) 17 Informal Logic 370; Douglas Walton, Appeal to Expert Opinion. Arguments From Authority (The Pennsylvania State University Press 1997) 234-6 (1997); Stephen Toulmin, Richard Rieke and Allan Jankin, An Introduciton To Reasoning 144 (2nd edn, Macmillan 1984).

34 Stephen Stitch and Richard Nisbett, 'Expertise, Justification, and the Psychology of Inductive Reasoning' in Thomas L. Haskell (ed), The Authority of Experts: Studies in History and Theory (Indiana University Press 1984) 236-7 (' $[\mathrm{I}] \mathrm{t}$ is a hallmark of an educated and reflective person that he recognizes, consults, and defers to authority on a wide range of topics... . Few educated laypersons would consider questioning the consensus of authorities on the authenticity of a painting, the cause of an airline crash, or the validity of a new theorem. Indeed, it is our suspicion that one of the principle effects of education is to socialize people to defer to cognitive authorities.').

35 Friedman (n 10) 68.

36 Barnett and Finnemore (n 20) 20. 


\section{SOME MARKS OF AUTHORITY IN INTERNATIONAL LAW}

'What does it matter who is speaking?'37 This famous Beckettian line accurately describes the operation of what has been called 'the pure or ideal case of persuasion through rational argument. ${ }^{38}$ In a case like this, what is said is in principle all that matters. In contrast, in an authority relation as described above, not only does 'who is speaking' matter, it in fact constitutes the foundation of that relation. ${ }^{39}$ In such a relation, the agent renounces its capacity to judge the persuasiveness of what is said and accepts the latter solely because it is said by a particular person. ${ }^{40}$

If what matters in an authority relation is 'who is speaking' but not what is said, how is the issue of whether the person who is speaking has authority determined? The answer lies in the 'marks' of authority that a person must possess to be able to claim authority. ${ }^{41}$ Simply put, the marks of authority refer to those properties that are regarded as 'deference-entitling properties' in a given community. ${ }^{42}$ Such properties are defined by Edward Shils as 'the qualities which are conventionally accepted as the ground on which deference is elicited or granted. ${ }^{43}$ They are 'socially accepted criteria ${ }^{44}$ that link authority to its social basis - an authority of a person or an institution exists because and to the extent that that person or institution possesses properties that are socially sanctioned as commanding deference. ${ }^{45}$

Considering the foundational role of the recognition of authority in authority relations, ${ }^{46}$ identifying what properties are considered as deference-entitling in a given community is crucial for a proper understanding of such relations. This section will focus on some specific 'marks' of authority that can be identified in international legal discourse with respect to the determination of the content of international law. While the 'marks' of authority outlined below are in no sense exhaustive, they aim to reflect some of the major trends at work.

Samuel Beckett, 'Texts for Nothing' in Samuel Beckett, The Complete Short Prose 1929-1989 (Grove Press 1995) 109.

38 Friedman (n 10) 67.

39 ibid 65 (stating that 'a command carries weight not because of what is said, but because of the fact that what is said is an order given by a particular person.'). See also, Peters (n 18) 218 (highlighting that in an authority relation, 'an order is obeyed or a decision is accepted simply because $\mathrm{X}$ gave it or made it.') (emphasis in original).

40 In political philosophy, this is often referred to as 'surrender of private judgment'. Friedman (n 10) 64.

41 ibid 70.

42 The phrase 'deference-entitling properties' is borrowed from Edward Shils. Shils (n 20) 278.

43 ibid 277.

44 Friedman (n 10) 71.

45 A mark of authority in this sense performs the same function as the skeptron discussed by Pierre Bourdieu. Pierre Bourdieu, Language and Symbolic Power (Harvard University Press 1991) 9 ('When an authorized spokesperson speaks with authority, he or she expresses or manifests this authority, but does not create it: like the Homeric orator who takes hold of the skeptron in order to speak, the spokesperson avails himself or herself of a form of power or authority which is part of a social institution, and which does not stem from the words alone.'). For an elaborate discussion of the metaphor of skeptron and its implications for international law, see Andrea Bianchi, 'On the Skeptron - Visions of Authority in International Law' in Gleider Hernandez (ed), Constructing Authority in International Law (OUP forthcoming).

46 Alexandre Kojève goes so far as to say that "Authority and the "recognition" of Authority are one and the same thing.' Kojève (n 18) 34. For a recent discussion of recognition in the context of authority relations, see Ole Jacob Sending, 'Recognition and liquid authority' (2017) 9 International Theory 311, 328. 


\section{A. Process}

To illustrate the role of process as a mark of authority in international law, it might be helpful to reflect on the sustained scholarly and institutional attention that the theme of fragmentation of international law has received in the last two decades. From the volume and intensity of the discussions that this theme has generated, an uninformed observer might conclude that in the last two decades the international legal order has been facing a problem that it had never seen before. The proponents of those discussions are, however, unanimous in acknowledging that fragmentation has always been an inherent feature of international law, since the latter notoriously lacks centralized law-making and law-ascertaining machinery. ${ }^{47}$ Indeed, international law has been traditionally described as embodying a 'boundless legal relativism', whereby each state is entitled to its own view of international law with no higher authority being capable of determining which view is 'correct'. ${ }^{48}$ Disturbing though it may appear, this state of affairs has never been regarded as a threat to the very existence of international law. One plausible explanation for this is that what heen termed 'the power of auto-interpretation' has never been considered unlimited. ${ }^{49}$ But more importantly, differences between states' subjective and arguably selfserving views about what the international law is on a particular point have never been regarded as a threat to the objective existence of international law precisely because they were deemed subjective and arguably self-serving.

One reason why fragmentation of international law has become a prominent theme in the last two decades is that it has taken a new form due to the proliferation of international adjudicatory bodies and the concomitant phenomenon of divergent interpretations of the same law by such bodies. Since third-party adjudicatory bodies are expected to say what the law is from an independent and impartial standpoint, divergent interpretations of the same law by two or more international courts or tribunals or court-like institutions came to be regarded as a more serious challenge to the viability of international law as an objective legal order.

47 See eg, James L Brierly, The Law of Nations. An Introduction to the International Law of Peace (Clarendon Press 1949) 76; Fragmentation of International Law: Difficulties Arising From the Diversification and Expansion of International Law. Report of the Study Group of the International Law Commission Finalized by Martti Koskenniemi, International Law Commission, Fifty-eighth session, A/CN.4/L.682, 13 April 2006, para 486.

48 Paul Reuter, 'Principes de droit international public' in (1961) 103 Recueil Des Cours 440. See also, Hersch Lauterpacht, The Function of Law in the International Community (Clarendon Press 1933) 3 (" $[\mathrm{T}]$ he theory of the sovereignty of States reveals itself in international law mainly in two ways : first, as the right of the State to determine what shall be for the future the content of international law by which it will be bound ; secondly, as the right to determine what is the content of existing international law in a given case ... The second aspect connotes that the State is in principle the sole judge of the existence of any individual rules of law, applicable to itself.'); Air Service Agreement of 27 March 1946 between the United States of America and France, 18 Reports of International Arbitral Awards 417, 483, para 81 ('Under the rules of present-day international law, and unless the contrary results from special obligations arising under particular treaties, notably from mechanisms created within the framework of international organizations, each State establishes for itself its legal situation vis-à-vis other States.').

49 Jules Basdevant, 'Règles générales du droit de la paix' in (1936) 58 Recueil Des Cours 588 (stating that while every state has the power to interpret its rights and obligations, it must do so 'honestly'). See also, Lake Lanoux Arbitration, 12 Reports of International Arbitral Awards 281, 310 ('It is for each State to evaluate in a reasonable manner and in good faith the situations and the rules which will involve it in controversies.'). 
What this episode shows is that because interpretations of their international law commitments by the states acting individually have been treated with suspicion, those features of content-ascertainment processes that are thought to eliminate or reduce the risks of self-serving subjective interpretations are granted significant weight in international law. In other words, while 'the potential of impartiality, of objectivity, disinterestedness' is a mark of authority in general, ${ }^{50}$ the structural features of international law have furnished fertile ground for it to flourish. For instance, due to the independence, impartiality and adversarial nature of judicial and quasijudicial proceedings, statements of international law offered in such proceedings tend to be equated with international law itself. ${ }^{51}$

Multiple examples of this trend can be found in international legal discourse. The Human Rights Committee recently highlighted the importance of its own interpretations of the Covenant on civil and political rights by pointing to possibly nefarious consequences of unilateral interpretations of the Covenant by states. ${ }^{52}$ More specifically, the Committee has accounted for the 'authoritative' nature of its 'views' as follows:

While the function of the Human Rights Committee in considering individual communications is not, as such, that of a judicial body, the views issued by the Committee under the Optional Protocol exhibit some important characteristics of a judicial decision. They are arrived at in a judicial spirit, including the impartiality and independence of Committee members, the considered interpretation of the language of the Covenant, and the determinative character of the decisions. 53

Similarly, when relying on their interpretations of the Covenant on civil and political rights and the African Charter on human and people's rights, the ICJ emphasized that both the Human Rights Committee and the African Commission on Human and Peoples' Rights were 'independent' bodies specifically established by treaties 'to ensure compliance' with those instruments and 'to monitor [their] sound application. $^{54}$

The press release issued by the UN Office of the High Commissioner with respect to the Julian Assange case also highlighted that the authority of the findings

50 Kojève (n 18) 23. Kojève distinguishes four 'pure' types of authority one of which is the authority of the judge. ibid 14-16.

51 On this tendency in international law, see Jean Combacau, 'Les réactions de la doctrine à la création du droit par le juge en droit international public' in (1980) XXXI Travaux De L'association Henri Capitant 401; Jean d'Aspremont, 'If International Judges Say So, It Must Be True: Empiricism or Fetishism?' (2015) 4 Esil Reflections.

52 'Human Rights Committee considers report of the United States', Press Release of the Office of the High Commissioner for Human Rights, 14 March 2014 ('Committee Members were very concerned at the United States' unilateral interpretation of the Covenant. For example, it had continuously been the view of the Committee that non-refoulement was covered by the Covenant. What would happen if all States parties had their own interpretation in that regard?').

53 General Comment No 33, The Obligations of States Parties under the Optional Protocol to the International Covenant on Civil and Political Rights, CCPR/C/GC/33, 25 June 2009, paras 11, 13. 
of the Working Group on Arbitrary Detention 'derive[d] from the collaboration by States in the procedure ... [and] the adversarial nature of is findings. ${ }^{55}$ One can find similar propositions in international legal scholarship. ${ }^{56}$

The role of process as a mark of authority is not limited to adjudicatory or quasiadjudicatory bodies. For instance, the authority of the International Committee of the Red Cross, which is widely regarded as 'a particularly authoritative interpreter' of international humanitarian law, ${ }^{57}$ has been explained by the perceived 'neutrality, impartiality and independence' of that institution. ${ }^{58}$ Similarly, the authority enjoyed by the International Law Commission among public international lawyers has been linked to the fact that 'its work is subjected to the review of the Sixth Committee and to periodic, thoughtful comment by states. ${ }^{59}$

\section{B. Socially Consecrated 'Superior Knowledge'}

Knowledge is generally regarded as a potential source of cognitive or epistemic authority. ${ }^{60}$ With the increasing diversification of knowledge, cognitive or epistemic authority can rarely be universal: a person can be a cognitive authority for another person only with respect to a specific field of knowledge in which she can successfully claim 'superior' knowledge. ${ }^{61}$ But how can cognitive authority be recognized if the knowledge grounding the latter is not available to everyone? Modern societies offer a variety of criteria to serve this purpose, ranging from educational credentials to certification by peers. ${ }^{62}$

Similar trends can be observed in international law. Consider the deference granted to specialized adjudicatory and quasi-adjudicatory bodies in their field of operation due to their specialization. What we may be observing here is a division of interpretive labour akin to what the philosopher Hillary Putnam called 'division of linguistic labor'. Putnam observes that every linguistic community displays a division of labour as to the meaning of a series of terms. Using the example of gold, he suggests that our community operates as a factory in which 'some people have the job of wearing gold wedding rings, other people have the job of selling gold wedding

55 'Julian Assange arbitrarily detained' (n 5).

56 See, eg, Georg Schwarzenberger, A Manual of International Law (6th edn, Professional Books 1976) 30 (explaining that judicial decisions carry great weight because 'before a decision is handed down, the case has been exhaustively argued by council from both sides.').

57 Steven R Ratner, 'Law Promotion Beyond Law Talk: The Red Cross, Persuasion, and the Laws of War' (2011) 22 European Journal of International Law 472.

58 Prosecutor $v$ Simic et al, Case No IT-95-9, Decision on the Prosecution Motion under Rule 73 for a Ruling concerning the Testimony of a Witness, 27 July 1999, para 51 (Int'l Crim Trib Former Yugo). See also, Francois Bugnion, The International Committee of the Red Cross and the Protection of War Victims (Macmillan Education 2003) 919 (accounting for the authority of the ICRC's interpretation of humanitarian law by reference to its being 'an impartial humanitarian institution.').

59 David D Caron, 'The ILC Articles on State Responsibility: The Paradoxical Relationship between Form and Authority' (2002) 96 American Journal of International Law 867.

60 Friedman (n 10) 80-81. See also, Richard E Flathman, The Practice of Political Authority. Authority and Authoritative (The University of Chicago Press 1980) 16.

61 Wilson (n 28) 13.

62 Richard T De George, 'The Nature and Function of Epistemic Authority' in R Baine Harri (ed), Authority: A Philosophical Analysis (The University of Alberta Press 1976) 83. 
rings, still other people have the job of telling whether or not something is really gold.63 In a broadly similar vein, it seems that specialized adjudicatory or quasi-adjudicatory bodies are increasingly regarded as being bestowed with the mission to determine the 'true' meaning of the legal provisions the implementation of which they are in charge to monitor.

A good illustration of such specialization operating as a 'deference-entitling' property $^{64}$ is provided by the case law that the International Court of Justice has developed in the last two decades. ${ }^{65}$ In the Bosnian Genocide case, the Court stressed that it attached 'the utmost importance' to 'the factual and legal findings made by the ICTY in ruling on the criminal liability of the accused before it' and declared to have taken 'fullest account' of the relevant ICTY's trial and appellate judgments. ${ }^{66}$ In a subsequent judgment, the Court stressed that 'only . . . in exceptional circumstances' would it depart from such findings. ${ }^{67}$ Earlier, the Court had relied on concluding observations, general comments and views of the Human Rights Committee without raising any question as to whether they were technically binding or not. ${ }^{68}$ More recently, the Court pointed out that:

Although the Court is in no way obliged, in the exercise of its judicial functions, to model its own interpretation of the Covenant on that of the Committee, it believes that it should ascribe great weight to the interpretation adopted by this independent body that was established specifically to supervise the application of that treaty. ${ }^{69}$

In its latest advisory opinion, the Court relied on a general comment of the Human Rights Committee adopted 'on the basis of 30 years of experience in the application of [the Covenant's provision on equality before the courts and tribunals]. ${ }^{70}$ This trend is all the more remarkable in view of the ICJ's long-

63 Hilary Putnam, 'The Meaning of "Meaning”' (1975) 7 Minnesota Studies in the Philosophy of Science 144, 145.

64 Shils (n 20) 278.

65 On the relationship between the ICJ and specialized adjudicatory bodies, see Marcelo Kohen, 'Considerations About What Is Common: the I.C.J. and Specialised Bodies', in Pierre d'Argent, Beatrice I Bonafè and Jean Combacau (eds), Les limites du droit international: essais en l'honneur de Joe Verhoeven (Bruylant 2014) 287-99.

66 Application of the Convention on the Prevention and Punishment of the Crime of Genocide, ICJ Reports 2007, 43, 209. See also, Andrea Gattini, 'Evidentiary Issues in the ICJ's Genocide Judgment' (2007) 5 Journal of International Criminal Justice 900.

67 Application of the Convention on the Prevention and Punishment of the Crime of Genocide, ICJ Reports 2015, 3, 137.

68 Legal Consequences of the Construction of a Wall in the Occupied Palestinian Territory, ICJ Reports 2004, $136,179-80$.

69 Ahmadou Sadio Diallo (n 54), 664. The Court has extended the same reasoning to regional human rights bodies. ibid ('Likewise, when the Court is called upon, as in these proceedings, to apply a regional instrument for the protection of human rights, it must take due account of the interpretation of that instrument adopted by the independent bodies which have been specifically created, if such has been the case, to monitor the sound application of the treaty in question.').

70 Judgment No.2867 of the Administrative Tribunal of the International Labour Organization upon a Complaint Filed against the International Fund for Agricultural Development, ICJ Reports 2012, 10, 27. 
established tradition to treat the jurisprudence of other courts and tribunals with relative indifference. ${ }^{71}$

There may be strategic reasons behind this attitude. Deference to the findings of specialized bodies arguably reduces the 'persuasion cost' and reinforces the legitimacy of a decision by making it appear as an objective outcome not depending on the identity of a particular decision-maker. Moreover, a decision conflicting with such findings would normally have to satisfy the burden of its own justification and that of explaining why those findings are considered to be wrong. But as Chaim Perelman once pointed out, pretending to argue would only make sense if the process of argumentation (or a particular argument) is thought to be of value in many cases. ${ }^{72}$ If deference to specialized bodies is seen to be of such strategic interest, it is because they actually command broad deference in practice.

Authority based on specialized knowledge is likely to expand with the increasing technicization of international law, given that knowledge of heavily technical areas is not readily accessible to everyone, but rather tends to be the focus of a relatively narrow group of specialists. This explains, for instance, that investment arbitration tribunals frequently rely on treatises on the law and economics of compensation and damages published by legal scholars and practitioners. ${ }^{73}$ But the phenomenon of knowledge-based authority is not limited to specialization as the latter is ordinarily understood, whether technical or otherwise. For instance, the International Law Commission enjoys such authority even though its institutional expertise is not limited to any particular branch of international law, still less to anything one could qualify as technical. Likewise, the Appellate Body of the WTO seems to rely on scholarly writings mostly with respect to general international law matters, which lie outside its area of institutional expertise. ${ }^{74}$

71 Hugh Thirlway, The Law and Procedure of the International Court of Justice. Fifty Years of Jurisprudence (OUP 2013) vol I, 248, n 471 (reporting the existence, in 1960s, of 'an unwritten rule of a drafting that the Court only referred specifically to its own jurisprudence, never to arbitral awards.'); Maurice Mendelson, 'The International Court of Justice and the Sources of International Law' in Vaughan Lowe and Malgosia Fitzmaurice (eds), Fifty Years of the International Court of Justice. Essays in Honour of Sir Robert Jennings (CUP 1996) 83 (explaining that 'even though there are other international courts in existence today, the ICJ is regarded, and presumably regards itself, as the supreme public international law tribunal, as such would not wish to be seen to rely too heavily on the jurisprudence of other bodies.').

72 Chaïm Perelman, 'Les cadres sociaux de l'argumentation [avec Discussion]' (1959) 26 Cahiers Internationaux De Sociologie 131 ('The process of argumentation must be of interest and value in a great number of cases for one to take the trouble to pretend to argue. It is because a currency is in circulation and possesses a value that one takes the trouble of making counterfeit money.').

73 Sistem Mühendislik Inşaat Sanayi ve Ticaret A v Kyrgyz Republic (Award, 9 September 2009), ICSID Case No ARB(AF)/06/1, para 189 (referring to a treatise by Sergei Ripinsky and Kevin Williams in support of the proposition that what matters for a fair market valuation is not the actual profits and losses, but those anticipated at the time of the expropriation); AWG Group Ltd $v$ The Argentine Republic (Award, 9 April 2015), para 89 (relying on the description of valuation approaches provided in a treatise by Irmgrad Marboe); Bernhard von Pezold and Others v. Republic of Zimbabwe (Award 28 July 2015), ICSID Case No ARB/10/15, paras 681, 693, 698 (relying on a treatise by Borzu Sabahi with respect to the legal regime of the remedy of restitution); Flemingo DutyFree Shop Private Limited v. Republic of Poland (Award, 12 August 2016), para 899 (referring to a treatise by Sergei Ripinsky and Kevin Williams and another by Mark Kantor in support of the proposition that post-valuation data and events can be relevant in assessing damages and the proper discount rate).

74 Sondre Torp Helmersen, 'The Use of Scholarship by the WTO Appellate Body' (2016) 7 Goettingen Journal of International Law 326, 331. 
Whether it is specialized or not, what matters with respect to knowledge is not its real existence, but its consecration through what Bourdieu calls social investiture'. ${ }^{75}$ All members of a specialized body may not actually be experts in the field at issue. Likewise, the members of the International Law Commission may not all enjoy particular eminence in the discipline of international law. But because the knowledge of those institutions is socially recognized, it is capable of resisting 'all practical refutations. ${ }^{76}$ As Bourdieu points out, social consecration is 'an act of social magic ... [that] can create difference ex nihilo. ${ }^{, 77}$ Such consecration is often facilitated by a formal requirement of specialized or 'recognized' competence in the relevant field. ${ }^{78}$

What explains the deference attached to the ICJ's pronouncements on public international law matters is also a social consecration of its 'superior knowledge'. In practice, the ICJ is commonly treated as 'the supreme public international law tribunal'. ${ }^{79}$ This situation does not seem to have changed with the multiplication of international adjudicatory bodies. On the contrary, international courts and tribunals operating in specialized areas of international law have been generally deferential to the ICJ when it comes to public international law matters. ${ }^{80}$ One cannot explain the ICJ's generally successful claim to interpretive 'monopoly' over public international law matters by pointing to any formal rule. While the ICJ is and has always been the only standing international court with general jurisdiction over interstate disputes theoretically capable of adjudicating any matter of public international law, it enjoys no formal superiority over any other international court or tribunal. But generations of so-called 'generalist international lawyers' have equated public international law with its representation by the ICJ, socially consecrating the Court's standing as 'the supreme public international law tribunal'. Their view of what it takes to be an

76 ibid 124.

77 ibid 119, 120.

78 See eg, International Covenant on Civil and Political Rights, Article 28(2) ('The Committee shall be composed of nationals of the States Parties to the present Covenant who shall be persons of high moral character and recognized competence in the field of human rights'); Statute of the International Tribunal for the Law of the Sea, Article 2(1) ('The Tribunal shall be composed of a body of 21 independent members, elected from among persons enjoying the highest reputation for fairness and integrity and of recognized competence in the field of the law of the sea.'); Understanding on rules and procedures governing the settlement of disputes (Annex 2 of the WTO Agreement), Article 17(3) ('The Appellate Body shall comprise persons of recognized authority, with demonstrated expertise in law, international trade and the subject matter of the covered agreements generally.').

79 Mendelson (n 71) 83.

80 See the following recent contributions discussing different contexts: Dean Spielmann, 'Fragmentation or Partnership? The reception of ICJ case-law by the European Court of Human Rights' in Mads Andenas and Eirik Bjorge (eds), A Farewell to Fragmentation. Reassertion and Convergence in International Law (CUP 2015) 173; Eva Kassoti, 'Fragmentation and Inter-Judicial Dialogue: The CJEU and the ICJ at the Interface' (2015) 8 (2) European Journal of Legal Studies 21; Alain Pellet, 'The Case Law of the ICJ in Investment Arbitration' (2013) 28 (2) ICSID Review 223; Joost Pauwelyn, 'Interplay Between The WTO Treaty and Other International Legal Instruments and Tribunals: Evolution After 20 Years of WTO Jurisprudence' <https://papers.ssrn.com/sol3/Papers.cfm?abstract_id=2731144> accessed 15 January 2018. 
accomplished international lawyer has helped perpetuate that tradition across generations. $^{81}$

As Bourdieu explains, social investiture of a person produces powerful 'symbolic' effects, transforming both 'the representations others have of him and above all the behaviour they adopt towards him' and 'the representation that the invested person has of himself, and the behavior he feels obliged to adopt in order to conform to that representation'. ${ }^{82}$ For instance, as a consequence of its social investiture as 'the supreme public international law tribunal', the ICJ itself claims deference from specialized courts and tribunals, ${ }^{83}$ and it seems that its claim in this regard is well understood and accepted by its potential 'competitors. ${ }^{84}$ Similarly, the ILC sees its work products as 'authoritative' regardless of whether they are transformed into binding treaties. ${ }^{85}$

\section{Reputation}

Since the social basis of authority primarily turns on deference-entitling characteristics that set a person or an institution apart from others, reputation is often regarded as a 'natural' mark of authority. While legal discourse is rarely vocal about its relevance, reputation often plays a prominent role in discriminating among conflicting decisions that are not subject to any formal hierarchy, especially so when such decisions deal with relatively less settled, or controversial matters. ${ }^{86}$

The system of investment arbitration is a case in point. As is well known, the world of investment arbitration is composed of separate arbitral tribunals set up

81 As has been highlighted by sociologists, professionalization implies not only a proper delimitation of the respective 'jurisdictions' of professions, but also a shared understanding of what is central to each of them. See Andrew Abbott, The System of Professions: An Essay on the Division of Expert Labor (The University of Chicago Press 1988). See also, Pierre Bourdieu, 'Le champ scientifique' (1976) 2 Actes De La Recherche En Sciences Sociales 92; Yves Dezalay, 'La Production Doctrinale Comme Objet et Terrain de Luttes Politiques et Professionnelles', in Yves Poirmeur and others (eds), La Doctrine Juridique (PUF 1993) 233.

82 Bourdieu (n 45) 119.

83 In the Bosnian Genocide case, the ICJ rejected the test of 'overall control' put forward by the ICTY Appeals Chamber for the purpose of determining whether an act of a person or group of persons is attributable to a State and confirmed the test it itself employed in the Nicaragua case. Application of the Convention on the Prevention and Punishment of the Crime of Genocide (n 66), 206-11. In so doing, the Court emphasized that while it 'attaches the utmost importance to the factual and legal findings made by the ICTY in ruling on the criminal liability of the accused before it, ... [t] he situation is not the same for positions adopted by the ICTY on issues of general international law.' ibid 209.

84 Concurring Opinion of Judge Peollonpää joined by Judge Sir Nicolas Bratza, in Al Adsani v. United Kingdom, European Court of Human Rights, Judgment of 21 November 2001 (“ $[\mathrm{W}]$ hen having to touch upon central questions of general international law, this Court should be very cautious before taking upon itself the role of a forerunner.'); Concurring Opinion of Judge Caflisch, joined by Judge Ziemele in Hirschhorn v. Romania, European Court of Human Rights, Judgment of 26 June 2007, para 2 ("[T]he International Court of Justice is not very favourably disposed towards specialised international courts [...] ruling on issues of public international law.')

85 See eg, Fourth report on State responsibility by Mr James Crawford, Special Rapporteur, A/CN.4/517, 2 April 2001, para 25 (stating that the ILC's work on state responsibility 'will be an authoritative text in the field it covers.').

86 This shows the link between authority and what has been called 'choice situations'. See Kim Lane Scheppele and Karol Edward Soltan, 'The Authority of Alternatives' (1987) 29 Nomos 170 (stating that '[a]uthority is constituted not by person A willing a particular state of affairs which is then carried out, but rather by person B being attracted to the state of affairs offered by alternative A and voluntarily choosing that option over others.') 
under separate investment treaties with no formal relationships amongst them. But this does not mean that investment arbitration tribunals ignore each other. Because investment treaties often contain identically or similarly worded standards of protection, tribunals often face largely similar interpretive issues such as the proper meaning and scope of the fair and equitable or the most-favoured nation treatment clauses. While such a system is bound to generate conflicting decisions, it also offers informal mechanisms whereby some decisions are regarded as more authoritative than others. Discriminating on the basis of the reputation of arbitrators is one such mechanism, which explains the wide-spread practice in published commentary of specifying the composition of investment arbitration tribunals. ${ }^{87}$ For instance, according to one experienced arbitrator 'decisions [of investment arbitration tribunals] are of variable quality' and '[i]n this regard, the quality of the arguments and those of the arbiters are determinative'.

El Paso $v$ Argentina shows this mechanism in action. In El Paso, the tribunal was confronted with a conflicting case law on the scope of the so-called 'umbrella clauses' in investment treaties. When summarizing the relevant case law, the tribunal found it relevant to specify who the president of the tribunal in each case was and concluded that it would follow 'the important precedents set by Tribunals presided over by Judge Feliciano, Judge Guillaume and Professor Orrego-Vicuña, ${ }^{89}$

The same pattern can be seen in the legal scholarship devoted to international investment law. Comparing the decision of an ICSID tribunal on the scope and effect of the 'essential security interests' clause of an investment treaty with the decision of the annulment committee in the same case, a prominent commentator frequently acting himself as an arbitrator stated:

In formal terms, the decision of an annulment committee has no greater precedential effect than an award. Nevertheless, ... the eminent experience in public international law of the Committee, suggest[] that great weight should be

87 See eg Rahim Moloo and Brian King, 'International Arbitrators as Lawmakers' (2014) 46 New York University Journal of International Law and Politics, passim; Campbell Mclachlan, Laurence Shore and Matthew Weiniger, International Investment Arbitration: Substantive Principles (2nd edn, OUP 2017), passim.

88 Gilbert Guillaume, 'The Use of Precedent by International Judges and Arbitrators' (2011) 2 Journal of International Dispute Settlement 14 and footnote 46. Another frequently appointed arbitrator Jan Paulsson distinguishes between 'awards by respected jurists' and others, and points out that the 'degree of persuasiveness' of an award may be affected by many factors, including, whether it is rendered 'by eminent persons careful of their reputation in the field' or 'by one-time arbitrators who might be surprised by their nomination'. Jan Paulsson, 'The Role of Precedent in Investment Arbitration' in Katia Yannaca-Small (ed), Arbitration under International Investment Agreements. A Guide to the Key Issues (OUP 2010) 710-11. See also, comments by Prosper Weil in Yas Banifatemi (ed), Precedent in International Arbitration (Juris Publishing 2008) 152 ('There are those awards that are a source of law, insofar as they have authority, they were rendered by prestigious arbitrators, $[\ldots]$ and they inspire the follow-up in the future, other awards.').

89 El Paso Energy International Company v. The Argentine Republic (Decision on Jurisdiction, 27 April 2006), ICSID Case No ARB/03/15, para 82. For an earlier example of such an approach, see In the Matter of Revere Copper and Brass, Inc. and Overseas Private Investment Corporation (Award, 24 August 1978) (1978) 17 International Legal Materials 1331 (departing from '[a] traditional international law approach [which] has been to leave questions of breach of contract to the municipal law governing the contract' on the basis of 'a series of decisions by Arbitration Tribunals, applying the views of outstanding international jurists.'). 
given to the Committee's categorical views on the central issues confronted in these cases. $^{90}$

A footnote to this statement clarifies that the members of the annulment committee were '[a] former president and judge of the International Court of Justice (Guillaume and Elaraby), together with the Whewell Professor of International Law in the University of Cambridge (Crawford). ${ }^{, 91}$

The role of reputation is of course not confined to adjudicatory bodies. A similar trend explains the European Court of Human Rights' reliance on reports by international human rights NGOs such as Amnesty International and Human Rights Watch regarding the human rights situation in particular countries. In Saadi v Italy, the Court made clear that the weigh it granted to such reports was warranted, among other things, in view of 'the authority and reputation of [their] authors. ${ }^{\text {92 }}$ Likewise, the interpretive authority of the International Committee of the Red Cross is often explained by reference to its reputation. ${ }^{93}$

\section{Authorship}

There is more than an etymological link between 'author' and 'authority'. As Alexander Nehamas points out, the relation between authors and their works has been historically described in terms of authority, with the author regarded as 'owner', and authority as 'possession'. 94 Authority as possession translates into the right of disposition, which, in the case of authored texts, primarily manifests itself through interpretation. ${ }^{95}$ In literature as in law, authors are generally thought to have special authority with respect to the meaning of their texts. ${ }^{96}$ Author occupies center stage in interpretation, acting as 'the principle of thrift in the proliferation of meaning 97 and imposing a 'final signified' on the text. ${ }^{98}$

Treaty interpretation is not an exception in this regard. Its very purpose is often described as consisting in giving effect to the common intention of the parties, which is a manifestation of authorial authority. ${ }^{99}$ The common interpretation given

90 Campbell McLachlan, 'Investment Treaties and General International Law' (2008) 57 International and Comparative Law Quarterly 390.

91 ibid footnote 168.

92 Saadi v Italy, Grand Chamber of the European Court of Human Rights, Judgment of 28 February 2008, para 143.

93 See eg, Ian Scobbie, 'The Approach to Customary International Law in the Study' in E Wilmshurst and S Breau (eds), Perspectives on the ICRC Study on Customary International Humanitarian Law (CUP 2007) 16.

94 Alexander Nehamas, 'Writer, Text, Work, Author' in A Cascardi (ed), Literature and the Question of Philosophy (Johns Hopkins University Press 1987) 267-8.

95 ibid 268.

96 See William E. Cain, 'Authors and Authority in Interpretation' (1980) 34 The Georgia Review 617.

97 Michel Foucault, Aesthetics, Method and Epistemology: Essential Works of Foucault 1954-1984 (James D Faubion ed, The New Press 1998) 221.

98 Roland Barthes, Images, Music, Text (Farrar, Straus and Giroux 1977) 147.

99 Malaysia v Singapour (Award, 30 October 2014), PCA CASE N ${ }^{\circ}$ 2012-01, para 43; European Communities - Customs Classification of Certain Computer Equipment, WT/DS62-67-68/AB/R, Report of the Appellate Body, 5 June 1998, para 84. 
by the parties to their treaty commitments is thus treated with special deference. ${ }^{100}$ The parties' claim to authority here is supported by what has been aptly termed 'paradox of knowing better' ${ }^{101}$ : if the stated purpose of treaty interpretation is to give effect to the common intention of the parties, a third party cannot claim to be in a better position to determine that intention than the parties themselves. $^{102}$

The role of authorship as a mark of interpretive authority came under the spotlight in the context of Article 1105 of NAFTA. Under Article 1105, protected investments are to be granted treatment in accordance with international law, including fair and equitable treatment'. The scope and meaning of that provision caused a significant controversy, in particular, after one award held that Article 1105 imposed obligations of transparency and predictability, ${ }^{103}$ and another reached the conclusion that treatment prescribed by Article 1105 was not limited to the minimum standard of treatment under international law. ${ }^{104}$ NAFTA Parties, acting through the Free Trade Commission, an intergovernmental body under NAFTA, responded to these awards by issuing an interpretive Note, with the stated purpose 'to clarify and reaffirm the meaning of certain of [the] provisions' of Chapter 11 of NAFTA after 'having reviewed the operation of proceedings conducted' by Chapter 11 tribunals. ${ }^{105}$ Notably, the interpretive Note rejected the above interpretations of Article 1105 advanced by some tribunals, and stated that Article 1105 prescribes the customary international law minimum standard of treatment, and not any treatment 'in addition to or beyond' that standard. All subsequent NAFTA tribunals deferred to the interpretation set forth in the FTC Note. The $A D F$ tribunal summarized the state of the post-FTC Note interpretive affairs by describing the FTC interpretations as 'a mechanism for correcting . . . interpretative errors' and observing that ' $\mathrm{n}] \mathrm{o}$ more authentic and authoritative source of instruction on what the Parties intended to convey in a particular provision of NAFTA, is possible. ${ }^{, 106}$

100 So much so that such interpretation is referred to as 'authentic' interpretation, open only to the contracting states. Question of Jaworzina, 1932 PCIJ (ser B) No 8, 6, 37 ('It is an established principle that the right of giving an authoritative interpretation of a legal rule belongs solely to the person or body who has power to modify or suppress it.').

101 Guy De Lacharrière, La Politique Juridique Extérieure (Economica 1983) 172; Martti Koskenniemi, From Apology to Utopia. The Structure of International Legal Argument (CUP 2005) 347.

102 Understandably, this phenomenon is not limited to treaty rules. Julia Black points out that one of the bases of the interpretative authority that the transnational regulatory regimes such as the International Accounting Standards Board, the International Organisation of Standardisation and the Forest Stewardship Council claim for their interpretations of their own norms is that they have issued those norms. Julia Black, “'Says Who?” Liquid Authority and Interpretive Control in Transnational Regulatory Regimes' (2017) 9 International Theory 304.

103 Metalclad Corporation $v$ The United Mexican States (Award, 30 August 2000), ICSID Case No $\mathrm{ARB}(\mathrm{AF}) / 97 / 1$, para $70,76$.

104 Pope \& Talbot Inc $v$ The Government of Canada (Award on the Merits of Phase 2, 10 April 2001), paras 105-18.

105 Notes of Interpretation of Certain Chapter 11 Provisions, NAFTA Free Trade Commission, 31July 2001.

106 ADF Group Inc v United States of America (Award, 9 January 2003), ICSID Case No ARB (AF)/00/1, para 177. 


\section{SOME CONCEPTUAL IMPLICATIONS OF THE DEFERENCE- BASED APPROACH TO AUTHORITY}

\section{A. Authority and Hierarchy}

Conventional wisdom tends to associate authority with hierarchy. As the anthropologist Walter Miller commented, we are accustomed to think about authority as emanating from 'an elevated locus and flowing downward through prescribed channels'. ${ }^{107}$ The very vocabulary we use in connection with authority bears witness to this tendency. Miller provides telling examples: we speak of 'top', 'high-ranking' or 'lowly' positions and describe changes in the authority position of a person as 'rise' or 'fall'. ${ }^{108}$ What is peculiar about the authority experiences outlined above is that this vertical perspective is largely irrelevant to them. For instance, the authority of the ICJ in public international law matters has little to do with the ICJ's formal place in a ladder of authority positions in the international legal order. Likewise, no formal rule dictates that findings of specialized adjudicatory bodies be treated with deference by non-specialized ones. The basis of authority as discussed in this article is not a formally sanctioned power to bind actors in a subordinate position, but a social acceptance of a claim to deference. As such, it can manifest itself in contexts involving no formal hierarchy, which correspond to the default setting in international law.

\section{B. Audience-sensitivity of Authority}

Unlike bindingness, authority is not a black and white matter; it comes in different shades and degrees and is something of which one can have more or less. ${ }^{109}$ Depending on how much weight it carries with a particular audience, the authority of the same person or institution may vary. It is interesting to observe, for instance, that in investment arbitration, the authority of the ICJ is not felt with the same intensity depending on the composition of arbitral tribunals. While decisions or opinions issued by arbitrators with a public international law background are often replete with references to the case law of the ICJ, decisions issued by arbitrators with a different background often contain few if any such references. ${ }^{110}$ Thus, the ideational background of decision-makers matters a great deal as far as their authority figures

107 Walter B Miller, 'Two Concepts of Authority' (1955) 57 American Anthropologist 276.

108 ibid 277.

109 Wilson (n 28) 13. The language used by the ICJ when describing the deference owed to the interpretation of the Covenant by the Human Rights Committee is telling in this regard: '[The Court] believes that it should ascribe great weight to the interpretation adopted by this independent body that was established specifically to supervise the application of that treaty.' Ahmadou Sadio Diallo (n 54), 664 (emphasis added).

110 By way of illustration, compare the treatment of the issue of jurisdiction in the award rendered in Daimler Financial Services AG v Argentina (ICSID Case No ARB/05/1, 22 August 2012) rendered by a tribunal presided over by Professor Pierre-Marie Dupuy with the treatment of the same issue in the decision on jurisdiction rendered in Churchill Mining PLC and Planet Mining Pty Ltd v Republic of Indonesia (ICSID Case No ARB/12/14 and 12/40, Decision of 24 February 2014) by a tribunal presided over by Professor Gabrielle Kaufmann-Kohler. The oft-mentioned connection between the extensive references to the jurisprudence of the WTO Appellate Body in the Continental Casualty v. Argentina award and the fact that the president of the Continental Casualty tribunal was a then acting member of the Appellate Body is another case in point. See Anthea Roberts, 'Clash of Paradigms: Actors and Analogies Shaping the Investment Treaty System' (2013) 107 American Journal of International Law 55. Likewise, the preference expressed in the above-referenced El Paso v Argentina decision for the solutions reached by 
are concerned. In other words, deference relevance, like beauty, lies in the eyes of the beholder: what is a deference relevant property for one group may not be seen as such by another. Consider the ILC's practice to seek comments from the governments in its work of codification of international law. For traditional international lawyers who tend to have a state-centric view of their discipline, such practice is arguably deference-relevant. But the very same practice would be seen with suspicion by others for whom international law is not or should not be the exclusive province of states. ${ }^{111}$ Similarly, while the FTC's 2001 Interpretive Note was seen by many as entitled to special deference because of its provenance, it was criticized by others as lacking in proper process. ${ }^{112}$ What these experiences reveal is that the deference relevance of a property is not a universal phenomenon. It would be more accurate to talk about deference communities built around specific properties that each community considers to be deference entitling.

\section{Dynamic Nature of Authority}

The social grounding of authority brings to light its dynamic character. Authority can be gained or lost, and can increase or decrease over time. ${ }^{113}$ If a deference entitling property becomes more widely or equally distributed over time, it might lose in its deference relevance, since its importance as a discriminating factor is likely to decline in such circumstances. ${ }^{114}$ Thus, one can speculate that the multiplication of adjudicatory bodies might ultimately lead to a decreased importance of third-party pronouncements on the content of international law, since third-party adjudication may with time come to be seen as an unremarkable feature of the international legal order. As a result of the abundance of case law, this is already the case in investment arbitration where individual decisions are rarely seen as deference-inducing merely because they are rendered by independent adjudicators. The same phenomenon can also account for the diminished importance of scholarly writings in ascertaining the content of international law. As recently pointed out, 'in the nineteenth century, judicial decisions and the literature were littered with references to the founding fathers. ${ }^{115}$ No such influence can be ascribed to scholarly writings today. A plausible explanation is the increasing professionalization of the discipline of international law

tribunals presided over by public international lawyers was presumably not unrelated to the fact that two members of the tribunal were themselves public international lawyers.

111 For a telling example, see Philip Allott's well-known article on the ILC's work on state responsibility. Philip Allott, 'State Responsibility and the Unmaking of International Law' (1988) 29 Harvard International Law Journal 1.

112 See Charles H Brower, II, 'Structure, Legitimacy, and NAFTA's Investment Chapter' (2003) 36 Vanderbilt Journal of Transnational Law 79 (pointing out that the Note was issued 'without any prior public consultation' and without giving 'any warning to investors party to ongoing Chapter Eleven arbitrations.'; Gabrielle Kaufmann-Kohler, 'Interpretive Powers of the NAFTA Free Trade Commission Necessary Safety Valve or Infringement of the Rule of Law?' in Frédéric Bachand (ed), Fifteen Years of NAFTA Chapter 11 Arbitration (Juris Publishing 2011) 192 (highlighting the due process concerns caused by the FTC's Note).

113 Barnett and Finnemore (n 20) 20.

114 Shils (n 20) 285.

115 Sandesh Sivakumaran, 'The Influence of Teachings of Publicists on the Development of International Law’ (2017) 66 International and Comparative Law Quarterly 1. 
and the resulting wider distribution of the scholarly capital, which has arguably diminished the deference relevance of scholars.

Because it is never granted as a matter of 'natural' right, but is gained in social interactions, authority often goes hand in hand with competition. ${ }^{116}$ Competing claims to authority are a pervasive feature of international law in particular, since power relationships at the international level are rarely delineated along formal lines. Claimants to authority in international law constantly engage in struggles to win or keep recognition of their claims. New competitors can lay claims to a particular mark of authority. What should count as a mark of authority itself can be an object of competition. ${ }^{117}$ Since they carry the potential to transform existing authority relationships, such struggles often call for strategic behaviour. The example of the ICJ appears emblematic in this regard. For long the ICJ was the only visible international court and consequently enjoyed the first-mover advantage. ${ }^{118}$ The increasing judicialization of international law has changed this situation radically. ${ }^{119}$ While the Court initially tried to keep its 'monopoly' over authority to say what the international law is, ${ }^{120}$ it has lately become more willing to share that authority with specialized bodies by deferentially referring to their jurisprudence. Given the ICJ's traditional indifference to the case law of other bodies, ${ }^{121}$ this can plausibly be seen as part of the Court's strategizing for authority in a changed environment.

\section{Authority, Legitimacy and Contestation}

Since deference is not something that a person can grant herself, but is granted by others owing to that person's deference entitling properties, authority entertains complex relationships with legitimacy. Legitimacy often features in the very definition of authority. ${ }^{122}$ In Kojève's words, ' $[\mathrm{t}] \mathrm{o}$ deny the legitimacy of Authority is not to recognise it' and 'not to recognise an Authority is to negate it, and thereby destroy it. ${ }^{, 123}$ In this understanding, the phrase 'legitimate authority' denotes a redundancy. ${ }^{124}$ While attempts have been made to separate the two

116 On this aspect of authority, see Sending (n 20).

117 ibid 12.

118 Alain Pellet, 'Article 38' in Karin Oellers-Frahm and others (eds), The Statute of the International Court of Justice. A Commentary (OUP 2012) 858 (explaining the 'exceptional authority' of the ICJ by reference to, among other things, its 'precedence in time').

119 ibid 860 (stating that 'the "proliferation" of international courts and tribunals has put an end to the long-lasting quasi-monopoly of the World Court in the matter of international judicial law-making.').

120 The calls by the former Presidents of the ICJ, Stephen M Schwebel and Gilbert Guillaume, for the ICJ to provide advisory opinions on issues of public international law at the request of other international tribunals can be seen as part of such initial attempts. See Address to the Plenary Session of the General Assembly of the United Nations by Judge Stephen M Schwebel, President of the International Court of Justice, 26 October 1999; Address by H.E. Judge Gilbert Guillaume, President of the International Court of Justice, to the United Nations General Assembly, 26 October 2000. See (n 71) and the accompanying text above.

See eg, Blau (n 21) 308 ('The distinctive feature of authority is a belief system that defines the exercise of social control as legitimate'); Andrew Edgar and Peter Segwick, Cultural Theory. The Key Concepts (2nd edn, Routledge 2008) 22 (defining authority as '[c] oncept in sociology and political philosophy indicating the legitimate use of power.').

124 Ian Hurd, After Anarchy. Legitimacy and Power in the United Nations Security Council (Princeton University Press 2007) 61, footnote 116. 
concepts, ${ }^{125}$ they often seem to proceed from an unrigourous use of the concept of legitimacy or an insufficient attention to the fact that legitimacy does not necessarily mean the same thing in different registers. ${ }^{126}$ For instance, measured by sociological criteria, legitimacy is a matter of 'social credibility and acceptability' of a social position. ${ }^{127}$ In this definition, it is difficult to see how legitimacy and authority can be meaningfully decoupled, since there can be no authority without social credibility and acceptability.

It is sometimes said that the proposition that 'there is no illegitimate authority is troubling for both normative and conceptual reasons. ${ }^{, 128}$ This argument could be valid if normative legitimacy were the only register of legitimacy, and if the only function of the concept of legitimacy were to make normative evaluation possible. ${ }^{129} \mathrm{But}$ assessing the legitimacy of a social phenomenon is not necessarily the same thing as passing a value judgment on it. The proposition that a political regime enjoys a legitimacy based on its leader's charisma does not necessarily say something on that regime's moral worthiness or normative desirability. As Julia Black points out, 'the relevant criteria [for sociological legitimacy] are not those which an external observer (including a commentating academic) would see to be normatively valid or valuable; the relevant criteria are those being used by those who are interacting with the actor in order for them to accept ... its authority. ${ }^{, 130}$

Another argument advanced against equating authority with legitimacy is that more authority does not automatically translate into more legitimacy. This argument often rests on a juridical conception of authority as formal legal competence, and has, as such, little to do with the conception of authority outlined above. ${ }^{131}$

In another attempt to show that authority and legitimacy cannot be conflated, it is sometimes suggested that resistance to, and contestation of, authority cannot be

Michael Zürn, Martin Binder and Matthias Ecker-Ehrhardt, 'International Authority and its Politicization' (2012) 4 International Theory 69; Birgit Peters and Johan Karlsson Schaffer, 'The Turn to Authority Beyond States' (2013) 4 Transational Legal Theory 315; Karen J Alter, Laurence R Helfer and Mikael Rask Madsen, 'How Context Shapes the Authority of International Courts' (2016) 79 Law and Contemporary Problems 6, 7.

126 On different registers of legitimacy, see Richard H Fallon, 'Legitimacy and the Constitution' (2005) 118 Harvard Law Review 1787 (distinguishing between legal, sociological and moral concepts of legitimacy); Daniel Bodansky, 'Legitimacy in International Law and International Relations' in Jeffrey L Dunoff and Mark A Pollack (eds), Interdisciplinary Perspectives on International Law and International Relations: The State of the Art (CUP 2012) 327-9 (distinguishing between normative and descriptive legitimacy); Christopher A Thomas, 'The Uses and Abuses of Legitimacy in International Law' (2014) 34 Oxford Journal of Legal Studies 734 (distinguishing between legal, moral and social legitimacy). Black (n 102) 292. See also, Barnett and Finnemore (n 20) 20. Zürn, Binder and Ecker-Ehrhardt (n 125) 83; Peters and Schaffer (n 125) 334.

For a very insightful analysis of different possible functions of the concept of legitimacy, see Thomas Schultz, 'Legitimacy Pragmatism and Political Systems in International Arbitration Lawmaking: A Framework for Analysis' (manuscript in file with the author).

130 Black (n 102) 293. This does not mean that there is no connection between normative and sociological legitimacy; the normative legitimacy of an institution can contribute to its sociological legitimacy.

131 This is made clear by an example used in one study: 'If, for instance, the European Central Bank is assigned the competence to reject national budgets in addition to setting interest rates, it certainly has more authority; but would that mean that Bank activities are seen as more legitimate by all relevant actors?' Zürn, Binder and Ecker-Ehrhardt (n 125) 83. 
properly accounted for without keeping authority and legitimacy separate. ${ }^{132}$ But legitimacy is not an 'all or nothing' matter, and is perfectly compatible with resistance and contestation. In the conception outlined in this article, the deference entitlement of a person or an institution can, for instance, be challenged on the ground that the property that is the basis of the claimed deference does not really exist or is not a proper basis for deference. Such a challenge can ultimately succeed and undermine the belief system at the basis of the authority relationship. But to be effective, authority rarely needs universal acceptance, which means that isolated challenges to its claim to deference entitlement are unlikely to affect it. The United States have repeatedly objected to the Human Rights Committee's interpretation of the territorial scope of the Covenant on civil and political rights. ${ }^{133}$ It also expressed a series of methodological concerns with respect to the ICRC Customary International Humanitarian Law Study, pointing out that they called into question some of the Study's conclusions. ${ }^{134}$ But such challenges have not detracted of the deference that the Human Rights Committee's view on the territorial scope of the Covenant or the ICRC Study commands as long as those challenges remain isolated.

\section{CONCLUSION}

Bishop Hoadly is credited to have said that 'whoever hath an absolute authority to interpret any written or spoken laws, it is he who is truly the Law Giver to all intents and purposes, and not the persons who first spoke and wrote them. ${ }^{, 135}$ Such an 'absolute authority' does not exist in international law, but Bishop Hoadly's statement has the merit of stressing the importance of the authority to say what the international law is on a particular point. The concept of authority outlined in this article shows that it would be simplistic to dismiss an actor-as Secretary Kerry did-by pointing to the lack of its formal empowerment to issue binding decisions. Authority is not coextensive with formal juridical competence; it is a socially sanctioned deference entitlement. As such, it may exist in the absence of a formal juridical competence or on top of it. ${ }^{136}$

Further research can unpack other important aspects of the concept of authority discussed in this article. For instance, what makes a particular property deferencerelevant in the international legal community and how 'cognitive consensus' around deference relevance is formed could be interesting questions to investigate. ${ }^{137}$ Such an inquiry was attempted in this article with respect to the process. As discussed above, some structural features of international law such as the traditional

132 ibid. See also, Peters and Schaffer (n 127) 334.

133 Third Periodic Report submitted by the United States of America, CCRP/C/USA/3, 28 November 2005, para 3 and Annex I; Fourth Periodic Report Submitted by the United States of America, CCRP/ C/USA/4, 22 May 2012, paras 504-05.

134 John B Bellinger, III and William J Haynes II, A US Government Response to the International Committee of the Red Cross Study Customary International Humanitarian Law (2007) 89 International Review of Red Cross 433.

135 Cited in John Chipman Gray, The Nature and Sources of Law (Macmillan 1921) 125.

136 As Blau points out, '[t] he legal authority of management to assign tasks to subordinates is rarely questioned - there is willing compliance - but this legal authority does not and cannot encourage willingness to work hard or to exercise initiative.' Blau (n 21) 312. 
concentration of both law-making and law-ascertainment powers in the hands of states and the relative scarcity of independent 'law-declaring machinery' have contributed to the deference relevance of the process. A more systematic investigation along these lines could yield interesting insights into the functioning of the international legal community.

Likewise, other potential 'marks' of authority operating in international law could be identified. One possible candidate is tradition. While Weber's discussion of traditional authority ${ }^{138}$ might leave the impression that tradition plays no role in founding authority in social orders governed by rational legality rather than traditions, there is no reason to limit the relevance of tradition to authority relations in this manner. As pointed out by Gadamer, ' $[\mathrm{t}]$ hat which has been sanctioned by tradition and custom has an authority that is nameless, and our finite historical being is marked by the fact that the authority of what has been handed down to us - and not just what is clearly grounded - always has power over our attitudes and behavior. ${ }^{, 139}$ While in theory, there may be countless ways of doing a particular thing, tradition narrows the range of choices in the sense that the options that have not received the imprimatur of tradition do not appear as 'choosable' as those that have. ${ }^{140}$ Tradition has the effect of making habitual choices appear as 'obvious,' which is an important attribute of an authoritative alternative. ${ }^{141}$

While such further inquiries are necessary to fully appreciate the place of authority in the operation of international law, it is hoped that this article has succeeded in its more modest ambition to show that, in view of the role of authority in shaping the content of international law, any account of international law limited to formal legal entitlements would be not only conceptually impoverishing, but also empirically distorting. 